\title{
Hollywood Sinemasındaki \\ Software Anlatılarda Yer Alan \\ Posthümanist Bakış Açısını Oluş Felsefesi Dahilinde Okumak
}

Başvuru Tarihi: 20.09.2021 Yayın Kabul Tarihi: 14.12 .2021 Yayınlanma Tarihi: 30.12 .2021

\author{
Yıldız Derya Birincioğlu Vural ${ }^{1}$ \\ Üsküdar Üniversitesi, Iletişim Fakültesi, \\ Yeni Medya ve Iletişim Bölümü, İstanbul \\ derya.birincioglu@uskudar.edu.tr \\ (iD) ORCID: 0000-0003-0119-9341
}

\section{Öz}

Toplumsal olarak dijitalleşen dünyada robot, android ve yapay zekâ gibi olgularla insan etkileşimi artırılarak sanal ve gerçek dünyanın akış içerisinde olduğu ortak bir yaşam inşa edilmektedir. Bu ortak yaşamın yeni adı olan posthümanist felsefede; birey ve toplum, öznenin ara varlıklar olarak üretimini mümkün kılar. Başka bir deyişle posthümanist felsefe, akış ve çokluk gibi olgulara yönelmeyi gerektirir. Dünyanın teknolojik gelişimi, bu gelişimin gündelik yaşam pratikleri içerisinde yer alması ve bilgi toplumunun dönüşmesi, sinemanın anlatı yapısını şekillendiren konular arasında posthümanist söylemlerin artış göstermesine neden olur.

Film anlatıları dijitalleşen dünyanın üzerine kurgulanan akış ve çokluğa sahip olan yeni toplum felsefesine yönelik birbirinden farklı örnekler içerir. Bu bağlamda posthümanist felsefenin sinematografik kodlarını yorumlarken insan merkezli toplum felsefesinin sabit anlamlarının dışına çıkılabilir.

Bu çalışma software anlatılar olarak kategorilendirilen Simone (Andrew Niccol, Simone, 2003), Her (Spike Jonze, Aşk, 2013) ve Transcendence (Wally Psifter, Evrim, 2014) filmlerinde yer alan posthümanist felsefenin ikili sabit anlamları dışlayan ya da yeniden üreten yapısını incelemeyi amaçlamaktadır. Çalışma kuramsal altyapısını Deleuze ve Guattari'nin arzu ve oluş felsefesi, Rosi Braidotti'nin göçebe özneler ve posthuman ve Katherine Hayles'in posthümanizm kavramlarından oluşturmaktadır. Çalışmada betimsel analiz yöntemi kullanmaktadır. Sonuç olarak çalışmada insan sonrası teknolojilerin androsentrik bakış açısı ile sunulduğu, posthuman imgelerin göçebe öznelere dönüştürüldüğü, heteronormatif eril bakışın kadın imgesini metalaştırdığı söylenebilir.

Anahtar Kelimeler: Transhuman, posthuman, organsız beden, arzu makineleri, Deleuze.

\footnotetext{
${ }^{1}$ Doçent Doktor
} 


\title{
Reading The Posthumanist Perspective in Software Narratives in Hollywood Cinema
}

Application Date: 20.09 .2021

Accepted Date: 14.12.2021 Publishing Date: 30.12 .2021

\author{
Yıldız Derya Birincioğlu Vural ${ }^{2}$
}

Üsküdar University, Faculty of Communication,

Department of New Media and Communication, istanbul

derya.birincioglu@uskudar.edu.tr

(iD) ORCID: 0000-0003-0119-9341

\begin{abstract}
In the socially digitalized world, human interaction with robot, android and artificial intelligence is increased and a common life in which the virtual and real world are in a flow is built. In posthumanist philosophy, which is the new name of this common life; individual and society enable the production of the subject as intermediate beings. In other words, posthumanist philosophy requires turning to phenomena such as flow and multitude. The technological development of the world, the inclusion of this development in daily life practices, and the transformation of the information society cause an increase in posthumanist discourses among the subjects that shape the narrative structure of cinema.

Film narratives contain different examples of the new social philosophy, which has flow and multiplicity built on the digitalized world. In this context, when interpreting the cinematographic codes of posthumanist philosophy, one can go beyond the fixed meanings of human-centered philosophy of society. This study aims to explore the structure of the posthumanist philosophy in Simone (Andrew Niccol, 2003), Her (Spike Jonze, 2013) and Transcendence (Wally Psifter, 2014) which is categorized as software narratives, which excludes or reproduces double fixed meanings. The theoretical background of the study consists of Deleuze and Guattari's philosophy of becoming and desire, Rosi Braidotti's nomadic subjects and posthuman and Katherine Hayles's posthumanism concepts. The study uses descriptive analysis method. As a result, it can be said that posthuman technologies are presented with an androcentric perspective, posthuman images are transformed into nomadic subjects, and heteronormative masculine gaze commodifies the female image.
\end{abstract}

Keywords: Transhuman, posthuman, body without organs, the desiring machines, Deleuze.

\footnotetext{
${ }^{2}$ Associate Professor
} 


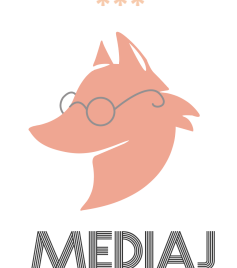

\section{Giriş}

Ana akım sinemanın dışında konumlanan ve ticari olanı reddeden anlatılar, genellikle kolektif olarak üretilen ve politik olanın yersizyurtsuzlaştırıldığı metinlere odaklanarak özne yapılarını değerlendirir. Bugün kimlik krizini üreten ana akım sinemanın posthümanist felsefenin izdüşümleri çerçevesinde özneyi kolektif bir çokluk içinde tanımlayıp tanımlamadığına odaklanmak bilindik yolların dışına çıkmak anlamı taşır. Posthümanizm sınırlarını bir tarafta insanın hayvana yaklaştığı biyolojik beden ile diğer tarafta ise insanın sibernetik organizmaya yaklaştığı teknolojik ilişkiler ağı ile belirler. Bu noktada bugüne kadar çok tartışılan ve teknofobik bakış açısının güçlenmesini sağlayan bu felsefenin izdüşümleri takip edilerek software anlatılarda yer alan bakış açısı yorumlanabileceği gibi ana akım sinemanın değişen ya da yeniden üretilen kodları da çözümlenebilir.

Anneke Smelik (2010) Cinema Fantasies of Becoming-Cyborg adlı çalışmasında toplumsal cinsiyet klişelerinin siborg imgesinde yeniden üretildiğini belirtir. Haraway'in Siborg Manifestosu adlı çalışmasının aksine hardware (donanım), software (yazılım) ve wetware (insan organizması) ayrımlamasından yola çıkan Smelik, cinsiyet asimetrisinin hümanist tortulardan kolay kolay sıyrılamadığına vurgu yapar. Bu noktada posthümanist felsefenin merkezinde yer alan Kartezyen düalizm anlayışını aşma ya da ters yüz etme pratiği sinema filmlerinde nasıl yer almaktadır? Sabit beden algısı sinemada yapı söküme uğratılmakta mıdır? İnsan sonrası teknolojilere yönelik kaygı dolu öngörülerin aksine anlatılarda yer alan kadın-erkek imgeleri maddi bir varlık olmanın ötesine taşınır mı? şeklindeki sorular çalışmanın temel bakış açısını oluştururken aynı zamanda kapitalizmin ürettiği sabit anlamları sorgulayan posthümanist yörüngenin sinemasal metinler aracılığıyla tartışılmasına da olanak sağlar. Bu bağlamda çalışma Hollywood sineması örnekleri arasında bulunan ve software anlatılar olarak kategorilendirilen Simone (Andrew Niccol, Simone, 2003), Her (Spike Jonze, Aşk, 2013) ve Transcendence (Wally Psifter, Evrim, 2014) filmlerinde yer alan posthümanist felsefenin ikili sabit anlamları dışlayan ya da yeniden inşa eden yapısına betimsel analiz ve söylem analizi yöntemleri kullanılarak odaklanmayı amaçlamaktadır. Çalışmada iki farklı analiz yöntemine yer verilmesinin temel nedeni film evreninde yer alan imgeler ve diyaloglar ile felsefi tartışmalar arasında ilişki kurabilmektir. Betimsel analiz aynı soru hakkında farklı düşünceleri ve tartışmaları aktarabilmek için kullanılmaktadır. Dört farklı aşamadan oluşan bu analizde ilk olarak araştırma sorularından yola çıkılarak veri analizi için çerçeve ve temalar oluşturulmaktadır. İkinci aşamada tematik çerçeveye göre elde edilen veriler işlenmekte ve düzenlenmektedir. Üçüncü aşamada düzenlenen veriler tanımlanmakta ya da alıntılanmaktadır (Karataş, 2015, s.73). Bu alıntılanma aşaması filmde yer alan diyaloglarında da kullanılmasına zemin hazırlamaktadır. Dördüncü aşamada bulgular temalar çerçevesinde açıklanmakta ve anlamlandırılmaktadır (Coşkun vd., 2019, s.322). Betimsel analizin üçüncü aşamasına ek olarak çalışmada söylem analizinden de yararlanılmaktadır. Söylem analizi; semantik ve sentantik dil yapısına odaklanılmasında sözcük, cümle ve söylemin bütün anlamının değerlendirilmesinde kullanılmaktadır (Erdoğan, 2012, s.125). Bu analiz çalışmada alıntılanan diyalogların bağlamsal ilişkilerinin kurulmasına, cümlelerin katmanlı yapılarının yorumlanmasına ve söylemlerin analiz edilmesine yardımcı olmaktadır. Bu noktada çalışmanın katmanlı anlam yapısına geçmeden önce kuramsal altyapısını oluşturan kavramları tartışarak başlamak anlamlı olabilir. 


\section{POSTHÜMANIZMI ADLANDIRMA SORUNU VE DELEUZECÜ KAVRAMLARI SESLI DÜŞÜNMEK}

İnsan ve teknoloji arasındaki ilişki dünyanın var olduğu an itibariyle başlar. İnsanın doğayı keşfinden fethine kadar geçen süre ile teknokültürün evrimi eşzamanlı ilerler. Hayles'in (1999) teknojenez kavramsallaştırmasında olduğu gibi insanın evrimsel yolculuğunu teknolojik gelişmelerden ayırmak mümkün değildir. Yonga, buhar, gemi, matbaa, telefon, bilgisayar ve yapay zekâ olmak üzere tüm icatlar insanın kendisini tanımladığı evrim yolculuğunda çoğalarak genişler. Özellikle yirmi birinci yüzyılda teknolojinin insanın ötesinde sibernetik özneler ile girdiği girift ilişki başta transhümanizm olmak üzere posthümanizm kavramının da tartışımasına neden olur.

Transhümanizm kavramının sınırlarını irdeleyerek başlamak gerekirse transhümanizm Cary Wolf'a (2010) göre hümanizmin yoğunlaştırılmış hali, Nick Bostrom'a (2005) göre insan doğasının iyileştirilebilirliğini savunan bir düşünce ve Pramod Nayar'a (2014) göre ise insan biyolojisinin sınırlarının teknoloji vasıtası ile aşılabileceğine yönelik görüştür (akt. Ağın, 2020, s.19). Tüm bu tanımlamalar transhümanizmin merkezinde insan olduğunu göstermektedir.

Transhümanizm insan biyolojisinin kapasitelerini teknoloji ve sosyal koşullar ile yeniden belirlerken tamamlanma, en üst ve nihai sonuna ulaşma aşamasını posthuman ${ }^{3}$ olarak değerlendirir. Bu sonuca ulaşana kadar aradaki geçiş sürecini ya da dönüşen organizmayı tanımlamak için kullanılan kavram ise transhuman olarak ifade edilmektedir. Transhuman, ağırlıklı olarak zihin-beden ayrımlamasından oluşan Kartezyen düalizmden beslenir. Liberal hümanist felsefede posthuman'ın tekinsiz ve rahatsız edici bir nitelik kazanması transhumanın ara kavram olarak varlık göstermesine neden olur. Bu noktada transhuman; süper-insan, ultrainsan yaratmaya odaklanırken bedensel, zihinsel, ahlaksal ve duygusal tüm çıkmazlar düalistik yapı içerisinden cevaplar üretir. Transhümanizm, insan merkezci bakış açısını türcü yaklaşımdan temel almaktadır. Beden anlayışından tam olarak arınmayan/arındırılmayan bu düşüncede sanal dünyada bedenin iyileştirilebileceği mantığı ile bedene bağımlıık devam eder. Beden üretiminin merkezde yer almasının nedenleri bizi ister istemez "fallus" merkezli dünya düşüncesine buradan da yola çıkarak anthropos (Evrensel insan-Erkek insan) ve Leonardo Da Vinci'nin, Vitruvius Adam (Mükemmel İnsan) kavramlarına götürmektedir.

Insan olma biçimlerinin eril, beyaz, kentli, standart bir dil konuşan heteroseksüel vatandaş olma gölgesinde inşa edildiğine vurgu yapan Rosi Braidotti, tarihsel süreç içerisinde yerkürede genel ölçütlerin dayatıldığını ifade eder. Braidotti, Aydınlanma döneminde İnsan Hakları Evrensel Bildirgesi'nde yer alan hakları erkeklerin elde ettiğini, kadınlar, Yahudiler, siyahlar ve çocuklar olmak üzere "erkek insan" şeklinde konumlandırılmayan tüm varlıkların iktidar yapıları tarafından değersizleştirme, yadsıma ve dışlanma ilişkilerine maruz kaldığını belirtir (Braidotti, 2019). Braidotti'ye göre insan-doğa ve insan-hayvan etkileşiminin zıtlıklar yapısından kurtulması

\footnotetext{
${ }^{3}$ Çalışmada posthuman kavramının kullanılma nedeni posthümanizm anlayışında bir sonluluk, öncelik ve sonralık düşüncesinin olmamasıdır. Cevirisi yapıldığında insanlık sonrası şeklinde kullanılan bu kavram sonluluk sorununu yaratmaktadır. Ancak posthuman belli kalıplar arasında yer alan aşina olunan insan algısının dışında olanı imlemektedir. Bu sebeple kavramın orijinal versiyonu ile kullanılması bu karışıklığı ortadan kaldıracaktır.
} 


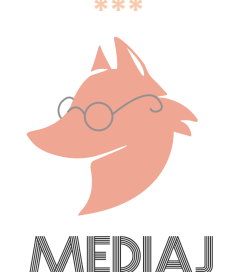

ve etkileşimin açıklanması için Rönesans insanının bir adım ötesine geçilmeli, dışlama ve aşağılama politikaları yapı bozuma uğratılmalıdır (Braidotti, 2014, s. 14). Posthümanizm "erkek insan" eksenini merkeze alan kodları sorgulama ve yapıbozuma uğratma girişimi ile Rönesans'ın ötesine ilerlemek için tünelin sonundaki ışık olarak görülmektedir. Özellikle şemsiye kavram olan posthümanizm içinde Kartezyen bakış açısının aşılması için temel engel olarak görülen erkek merkezli insan vurgusunun yansımaları feminist bakış açısı tarafından derinlemesine tartışılır. Bedene dair kalıpların, sınırların ve sınıflandırmaların sınırlandırıcı yapısına yönelik politikalar bu tartışmalarla yerle bir edilir.

Donna Haraway (2006), Siborg Manifestosu adlı çalışmasında insanın ikili karşıtlıklar üzerinden tanımlanamayacağını beden ve kimliğin bütüncül bir yapı taşıdığını metaforik olarak kullandığı siborg imgesi üzerinden ifade eder (s. 4). íkili karşıtlıkları sorgulamak için kullanılan bu direniş stratejisi kapitalizmin ayırııı beden ve kimlik politikalarına bütüncül bir bakış açısı ile yaklaşma imkânı sağlar. Haraway, düalistik ayrımlar hiyerarşisini sorgularken insan ve insan olmayanın tasavvurunda humus ve kompost kavramsallaştırmaları ile her iki varlığın da günümüz anlamlarından bağımsız, birliktelik anlamı taşıyacak bir figür olduğunu ifade eder (Haraway, 2016, s. 11-12, 30).

Rosi Braidotti ise Foucault'un Kelimeler ve Şeyler adlı çalışmasında kullandığı "I’homme” sözcüğü ile insanın ölümünden ziyade erkek merkezli insanlığın/evrenin ölümüne yönelik vurgu yapar (Braidotti, 2014, s. 33). Braidotti burada insanın doğayla bağının aşılması ve beraberinde doğaya ait olan bedenin aşılma çabasını sonluluğu aşma süreci olarak yorumlar. Ona göre ölüm bitimin aksine üretken sürecin farklı bir evresi anlamı taşır. Başka bir deyişle bilinç düzeyinde gerçekleşen ancak fiziksel yok oluşun henüz gerçekleşmediği bu süreçte yaşamın işgal edildiği süre boyunca üretkenliğine odaklanmak yerinde olur (Braidotti, 2014, s. 148). Bu noktada Braidotti'nin önerdiği yaklaşım insan merkezci yaklaşımın dışında yer alan zoe ${ }^{4}$ kavramına (insan merkezci olmayan yaşam) yönelmektir. Böylelikle insan kendini ve evreni, yaratım sürecinde oluşturduğu hümanist tortular düzleminde değil, kendisi dışında var olan çoklu aidiyetler ve kimlikler tarafından sürekli olarak yaratılan bir tanımlama süreci olarak görebilecektir.

Insan-doğa, insan-makine etkileşiminin birbirini dışlamadığı ve birbirine galip gelmediği bir konumlandırmanın yapıldığı posthümanizmde, transhümanizmin aksine insan, doğa ile kurduğu ilişki temelinde yapılandırılmaktadır. Diğer taraftan posthümanizm teknolojik gelişmelerle "insanı alt tür şekline dönüştürecek mi?" anksiyetesi ile değil, insanın dijitalleşmesini onaylayan bakış açısının dışında yer almaktadır. Posthümanizmde birey ve toplum öznenin farklı versiyonlarını -ara varlıkları- mümkün kılar. Bu sebeple disantropocentric (insan-merkezci olmayan) sistemlere odaklanır ve modernizmin ikili karşıtıklarını eleştirir. Başka bir deyişle, aklı insanı üstün kılan özellik olarak görmeyi reddeder. Katherine Hayles, posthümanizmi biyolojik

\footnotetext{
${ }^{4}$ Rosi Bradiotti'ye göre zoe kavramı antropos ve bios ayrımlarının yerini alır. Zoe türler arası üretken ve yaşamsal bir gücü ifade eder. Bu yaklaşımın temelinde tüm canlı maddeler dinamik ve kendi kendini organize eden bir yapıya sahiptir. Böylelikle doğa-kültür sürekliliği görünür hale getirilir (Bradiotti, 2014, s. 149). Aynı zamanda zoe insan dışı hayati gücü ve daha önce ayrılmış türler, kategoriler ve alanlar arasında düşünmemizi sağlayan varlıktır. Bradiotti'ye göre zoe merkezli eşitlikçilik enformasyonel ve bilimsel uygulamalara ilham verecek ileri kapitalizm tarafından türler arası metalaşma olgusuna direnecek posthuman düşüncesinin özünü oluşturmaktadır. Zoe merkezli çerçeve hem erkek insan ayrımlamasına meydan okunur hem de iktidar iliskileri, mevcut biyo-korsanlıklar, nekro-politikalar, sistematik mülksüzleştirmeler, dünya düzenin sürdürdüğü sosyal dışlamalar ve tahakküm biçimlerini yerle bir eder (Braidotti, 2019, s. 42-43).
} 


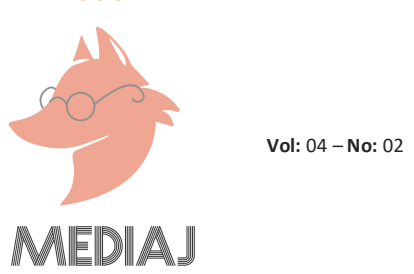

bileşenlerden ziyade enformasyona dayalı bir öznelliğin inşası olarak değerlendirir. Hayles'e göre posthuman heterojen bileşenlerden oluşan bütüncül bir yapıdır (Hayles, 1999, s. 3). Hayles (1999) bu bütüncül yapıyı; posthümanizmin hem zeki makineler ile bir olması, hem de makinelerin biyolojik organizma ile organizmanın içine gömülü olan enformasyon devreleri arasındaki anlamlı ayrımı çerçevesinde açıklar (s. 35). Ona göre posthuman yoğun ve çok yönlü bir kimliğe sahiptir. Bu yapı insanlığın sonu değil "belirli bir tür insanlığın" sonu anlamı taşımaktadır (Hayles, 1999, s. 286). Ayrıca Hayles posthuman ile bedenin kapitalizm ve iktidar ilişkilerine yönelik bir direniş yaratabileceğini de ifade eder. Hayles'ın bu direniş stratejisi Gilles Deleuze ve Felix Guattari'nin iktidar biçimlerine karşı bir başkaldırı olarak nitelediği organsız beden $^{5}$ (O.B.) kavramı ile birlikte düşünülebilir. Edimsel gerçekliğin başka tarzlarda yeniden edimselleşmesinin önünü açan organsız beden, yersizyurtsulaşır ve yeniden inşa (yer yurt edinir) edilir. Deleuze ve Guattari'ye göre organsız beden farklı konumlar içerisinde hareket edebilmeyi ifade eder (Deleuze ve Guattari, 2014, s. 169). Organsız beden bedene karşı değildir aksine hiyerarşik yapılanmalara karşıdır. Organların organizmaları oluşturuyor olma düşüncesini reddeder. Organsız beden, moleküler çokluk içerisinde dağılmış heterojen organlar anlamı taşır. Bu sebeple ölü bedenin yaşayan bedenin aksine daha dinamik ve seyahat eden bir beden olduğu iddia edilir (Deleuze ve Guattari, 2014, s. 287). Bu kavram insan bedeninin doğasını değiştirmek ve onu ilişkiler ağı ile etkileşimli bir şekle dönüştürerek şizoid bedeni yersizyurtsuzlaştırmak üzerine kuruludur (Deleuze ve Guattari, 2014, s. 183). Böylelikle merkezde yer alan iktidarın etki gücü yavaşlatılmaktadır.

Braidotti (2014) de iktidarın merkezsiz, dağınık, karmaşık, teknoloji odaklı ve yeni zıtıklar içeren yapısına posthümanizmin kümülatif yapısıyla cevap üretilebileceğini belirtir (s.37). Braidotti, Deleuze ve Guattari'nin sürekli oluş kavramsallaştırmasından yararlanarak insan ve posthuman varlıklar arasındaki ilişkiyi açıklar. İnsan ve posthuman sürekli oluş halinde kendi kendini düzenleyen maddenin canlılığına içkin göçebe öznelerdir. Deleuze ve Guattari'nin ontolojisi iktidar ya da bilgiden değil arzudan beslenir. Klasik felsefenin aksine temsil yerine farka odaklanan yazarlar, yerleşik dağılımların yerine sabit ve değişmez göstergelerin ötesinde yer alan rastlantısal noktalar ve göçebe dağılımlar ile ilişki kurar. Böylelikle fark politikası ve yeni özne tanımlamaları ile hiyerarşik ve kategorik bakış açısı sabit olan dışında anlamlar barındırır. Deleuze'e göre yerleşik dağılımlar; önceden belirlenmiş, kişilere ve mekanlara bölüştürülmüş, rijit ve dogmatik düşünceyi imlerken, göçebe dağılımlar; kapalı ve sınırlı bir alanı paylaştırmaktan öte açık, rastgele ve sınırları çizilmemiş bir mekâna dağılmayı ifade eder. Göçebelik olgusu sabit anlamlar üreten özne anlayışı üzerine kurulmaz. Kurucu özne düşüncesine karşı olan Deleuze, düşüncenin öncelendiği fikrinden uzak (töz olarak değil içkinlik düzleminde) olarak konumlandırma yapar (Deleuze ve Guattari, 2015, s. 210). Bu sebeple düşüncenin merkezinde yer alan fark politikası, tekrar anlayışı, akış ve oluş düşünceleri önem kazanmaya başlar.

Braidotti, Deleuze ve Guattari'nin "şimdinin gücünün burada ve an ile tamamen örtüşmemesi” açıklamasından yararlanır. Akış ve oluş kavramları ile öznenin sabit anlamlardan arındırılarak kimlik algısının başka çoklu evrenlere ve varoluş biçimlerine yönelik yeni bakış açıları oluşturacağını ifade eder. Başka bir deyişle sürekli oluş halinde bulunan özne "ne olmaktan çıktığımıza" (gerçekliğin sonu) dair kesin bir farkındalık yaratırken "ne olduğumuz algısı"na

5 Organsız beden kavramı çalışmada yer alan "Akış Felsefesi, Üst İnsan ve Arzu Makinalarının Sinemasal İnşası" başlığı altında yeniden tartışılacaktır. 


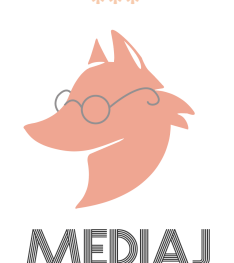

(sanalın hayat bulması) dair de farklı netlikler oluşturur. Sürekli akış doğrusal olmayan bir zaman sürekliliğinde her ikisini de mümkün kılar (Braidotti, 2019, s. 36-37). Bu noktada siborg imgesi baskın özne oluşumlarının yapısını göçebe özne figürasyonlarına dönüştürür. Beden ve iktidar ilişkilerini anlamlandırmaya yönelik fallus merkezci özne anlayışını yapıbozuma uğratan ve Deleuzecü azınlık-oluş ve öteki-oluş süreçlerinden temel alan göçebe özne kavramsallaştırması, yenilikçi özne metamorfozlarının tanımlanması için kullanılır (Bradiotti, 2019, s. 33). Burada Bradiotti, göçebe öznelliğin rizomatik yapısına dikkat çeker. Deleuze yaratıcı düşünme şeklini ifade etmek için bu kavramı kullanır. Yer altında yaşayan ve dallanıp çok sayıda kök üreten bu bitki ile düşünme arasında analoji kurar. Deleuze, tek kaynaktan beslenerek sürekli oluş içerisinde kendiliklerini çeşitlendiren bu uzamsal ve zamansal çokluğu iktidar temelli düşünce sisteminin yerine koyar (Sutton ve Jones, 2013, s. 22). Rizomun parçalara ayrılan ve her bir parçanın kendi içinde bir bütün oluşturan kümülatüf yapısı, posthümanizmin farklı yaklaşımlar ile kendini beslemesi ve büyümesi ile birlikte düşünülebilir. İnsanın sahip olduğu organizmalarla kümülatif bir yapı oluşturması rizomatik büyüme ile ilişkilendirilebilir. Çoğulluğu olumlayan bu bakış açısı postkolonyal, feminist, sınıf ve ırk gibi kategorilerden yararlanırken aynı zamanda sosyal, beşerî ve doğa bilimlerini içeren toplu bir yörüngeye de sahiptir. Rizomun hem bağımsız hem de heterojen yapısı tam da bu noktada posthümanizm ile benzerlik taşır. Braidotti'ye göre, merkezi ve birbirine bağlı fikirlerin genişleyerek organik bir şekilde büyüyen bu öznellik yapısında toplumsal mübadele ağlarında gerçekleşen etkileşim ile kimlikler kolektif bir özellik kazanır. Özne konumlarının çok katmanlı ve melez yapısı olumlu ve dönüştürücü özellikleri ortaya çıkarır. Öyle ki artık siborg imgesi metafor olmanın dışında göstergebilimsel bir işaret haline gelir (Braidotti, 2017, s. 20-23). Siborg imgesi Deleuze ve Guattari'nin rizomik yapıyı açıkladığı yabanarısı ve orkide döngüselliğinde ${ }^{6}$ olduğu gibi tek merkezli düşünce yapısının statik anlamlarını değiştirir. Insan ve insan sonrası varlıkların sürekli oluş döngüselliğine girmesini sağlayarak hümanizm merkezli anlamları yersizyurtsuzlaştırır.

\section{AKIŞ FELSEFESI, ÜST INSAN VE ARZU MAKINALARININ SINEMASAL INŞASI}

Deleuze ve Guattari'nin felsefesini oluşturan arzu politikaları, özdeşliklerden ziyade farklılıklara odaklanarak akışkan bir özellik kazanır. Deleuze ve Guattari arzu kavramını Freud'un psikoseksüel kuramı ve oedipal özne inşası üzerine yaptıkları eleştiri ile temellendirir. Yazarlar, Anti-Oedipus Kapitalizm ve Şizofreni adlı çalışmalarında Freud'un oedipus kompleksi ve bilinçdışı yapısını derinlemesine yorumlar. Onlara göre Freud'un arzu temsili yanlış ve baskılanmış bir temsildir. Freud arzuyu öznenin sahip olduğu eksiklik ile ilişkilendirir. Öznenin anneden mahrum kalması ile oluşan arzu bilinçdışına itilerek baskılanır (Holland, 2013, s. 97). Özne hiçbir zaman sahip olamayacağı imge repertuarlarını arzular. Freud'a göre tamlık vaadi ile şekillenen arzu,

\footnotetext{
6 "Yerinden etme hareketleri ve yer edinme işlemi nasıl göreceli, birbirine her zaman bağlı ve birbirinin içinde olmasın? Orkide bir imge yaratarak yerinden eder, eşekarısının iziyle görüntü yer edinir. Eşekarısı her şeye rağmen orkidenin bir üreme aracı haline geldiği için yerinden edilir. Ancak polenini taşıyarak tekrar yer edinir. Eşekarısı ve orkide, heterojen birimler olarak bir rizom oluşturur. İmgesini, gösteren şeklinde yeniden ürettiği için orkidenin eşekarısını taklit ettiği söylenebilir (mimesis taklit, yem, vesaire). Ancak bu sadece tabaka seviyesinde mümkündür-bir diğerinde, bir hayvan topluluğunu taklit eden bir bitki topluluğu gibi, iki tabaka arasındaki paralellik. Aynı zamanda, büsbütün farklı bir şey gerçekleşiyor: taklit değil, kodlamanın yakalanması, bir kodun üretim fazlası, değerliğinde bir artış, gerçek bir başkalaşma, orkidenin eşekarısı ve eşekarısının orkidesi olarak başkalaşır. Tüm bu başkalaşımlar, birinin yerinden edilmesini, diğerinin yeniden yer edinmesine sebep olur. İki başkalaşma da aralarında bağ kurar ve yoğunluk dönüşümlerinde röleler kurarak yerinden edilmeyi daha da ileriye taşır. Taklit ya da benzerlik yoktur, sadece herhangi bir belirleyici tarafından nitelenmez, ortak bir rizom tarafından oluşturulmuş bir kaçış çizgisindeki iki heterojen serinin patlaması vardır" (Deleuze ve Guattari, 2015, s. 10).
} 


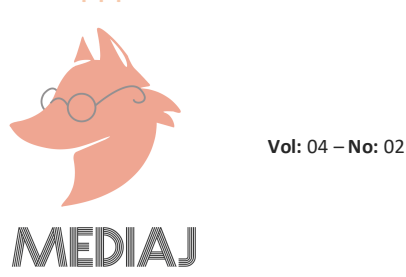

baskılanmak durumundadır ve arzunun kaynağını oedipus kompleksi oluşturur. Deleuze ve Guattari, Freud'un arzu işleyişini fark felsefesi ile dönüştürür ve pozitif bir unsur olarak tanımlanmasını sağlar. Deleuze ve Guattari'ye göre arzu; tüm yaşamı kapsayan, belirli sınırlar içerisine hapsedilemeyecek üretimsel bir enerjidir. Diğer taraftan arzu, öznenin içinde hapsolan toplumsal ilişkilerin ürünü olarak sosyal politik süreçlerle de ilişki içerisindedir. Toplum içindeki sosyal oluşumlar arzu politikalarından bağımsız değildir. Deleuze ve Guattari, bilinçdışı süreçleri oluşturan, kendi arzularını bilince dayatarak özne üzerinde suçluluk ve erk yaratan yaşamsal süreçlerin gruplaşmış arzu olduğunu ifade eder (Deleuze, 2014, s. 77-79). Yazarlar, pozitif fark felsefesiyle açıkladıkları arzuyu bir imgeye ya da objeye sabitlemez. Bu akışkan yapıda hiçbir şey önceden bilinmez, her şey oluş halindedir ve yeniden kodlanabilir. Anlamsız partiküllerin ve sayısız şeyin bir bağlam çerçevesinde bir araya getirilmesi ile oluşan saf içkin çokluğun oluşturduğu akış ile oedipus kompleksinin ötesinde şizoid bilinçdışı arzu üretimine işlerlik kazandırır. Baskı altındaki arzu özgürleştirilerek içkin bir şekle dönüşür (Holland, 2013, s. 87). Bu pozitif ve üretici arzu ile makinalar arasında ilişki kurulur. Özellikle kapitalizm ile birlikte beden haz üreten makinelere dönüşmüştür (Işık, 1996, s. 38). Mekanizma düşüncesi ile organizma fonksiyonları arasında bağlantı kurularak arzu sistemi açıklanabilir. Arzunun toplumsal bilinç dışından sıyrılarak özgürleşmesini amaçlayan yazarlar, bu kavramla soyut makineler arasında ilişki kurar. Deleuze ve Guattari'ye göre arzu, temsil ve üretimden önce olan her şeydir, başka bir deyişle duygu ve dünya aracılığıyla kendimiz dışında bizi oluşturan her şeydir. Arzu, özneden akan her şeyi ifade etmektedir. Arzu makinesi ise bu akış arasındaki bağlantıyı düzenlemektedir (Deleuze ve Guattari, 2014, s. 312). Makine yeni bağlantılarını kırılma ve bozulma ile gerçekleştirebilir. Yüzeyler arası politik göçebeliğe imkân sağlayan arzunun akışkanlık kazanması için bozulma zorunludur. (Deleuze ve Guattari, 2014, s. 39). Onlara göre beden, ilişki, sosyal gruplar, üretim ve olaylar "arzu makineleri"dir (Goodchild, 2005, s. 91, 142). Diğer taraftan psikanalizde öznenin oluşum sürecinde fallus önemli bir yer tutar. Oedipal yapıda baba yasası birincil, kadın ise ikincil konumdadır. Deleuze ve Guattari patriarkal değerlerin inşa edildiği bu yapıdaki özne tanımlamalarını da yadsır. Özne hiçbir zaman sabit bir varlık olmamalıdır (Holland, 2013, s. 97). Başka bir deyişle Deleuze ve Guattari, Freud'un psikoseksüel kuramını eleştirerek; oedipal öznenin ikili karşıtlıklar/molar sistem üzerine kurgulanışını, fallus merkezli şemada yer alan eksiklik olgusunu, eril durumlara göre inşa edilen çağrışım zincirlerini ve ataerkil aile dinamikleri ile ilişkilendirilen bağlantıları dışlar. Yazarlar oedipal özne kavramı yerine çoğul özne konumlamalarına işlerlik kazandıran göçebe özne kavramını ortaya koyar. Böylelikle sabit öznelliklere indirgenen ve eksiklik-tamlık antagonizmasından sıyrılan arzunun serbest akışı ile göçebe özne çoklu bağlantılar kurabilir. Özneyi farkın çeşitliliği ve çoğulluğu bağlamlarında açıklayan yazarlar, belirli bir yapı ve söylem çerçevesinde belirlenen özne tanımlamalarına karşı çıkar. Öznenin sonlu ve sabit kimlik yapıları ile hareketsiz anlamlarını yoğunluk, çokkatmanlılık ve dinamik bir süreklilik vurgusu ile dönüştürürler.

Deleuze ve Guattari bedenin oedipalleşmesini eleştirmek, sabit anlamların ve dilin dışında konumlandırılmasını sağlamak için organsız beden kavramını ileri sürer. Arzu makinelerinin önemli bir aygıtı olan organsız beden, aktif bir eylem biçimini ifade etmektedir. Sürekli bir oluşum içerisinde olan farklı alanlar ve dış dünya ile sonsuz bağlantı kuran organsız beden bir özne kimliği olmanın ötesine taşınır. Başka bedenlere de açımlanan ve yaylalardan oluşan organsız beden, kapitalizme karşı direniş stratejisi geliştirerek tüm iktidar biçimlerini yok eder ve bir bütünlük oluşturur (Deleuze ve Guattari, 2014, s. 166). Egemen, statik, majör ve imgesel 


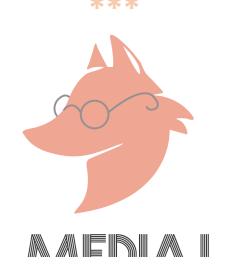

evreni aşan oluşları ifade eden organsız bedenin göçebe, azınlık ve minör bağlantı ağları kurarak hiyerarşik yapıya meydan okuması onun rizomatik ve dinamik özelliklere sahip olduğunu gösterir.

\section{Trancendence Filmindeki Rizomatik Yapı Analizi}

Transcendence filminde Dr. Will Caster ve Dr. Evelyn Caster bilince sahip olan bir bilgisayar üretmek ister. Uzun süre bunun üzerinde çalışan Dr. Caster katıldığı bir konferansta yapay zekâ karşıtlarının saldırısı sonucu zehirlenir. Saldırıdan sonra 1 aylık yaşam süresi kaldığını öğrenir. Bu süre zarfında kendi bilincini geliştirdiği bilgisayar ortamına aktarmaya çalışır. Kuantum ve nano teknolojiden yararlanarak oluşturduğu nanit adı verilen sistem ile Dr. Caster'ın bilinci doğa ve evren ile iletişim kurabilir hale gelir. Sistemin aşırı güçlenmesi ve insanlara nanitlerin aktarımı yapay zekanın dünya için tehlike olarak görülmesine neden olur. Artık Evelyn ve eski iş arkadaşı Faraday için kendini hızla yenileyebilen bu teknoloji dünyayı ele geçirecek robotların üretimine destek sağlamaktadır. Gezegeni, ekosistemi ve insanları kurtarmak için bilgisayar virüsünün sisteme entegre edilmesi ile yapay zekanın ortadan kaldırılması gerektiği düşünülür. Sisteme virüs bulaştırılır ancak doğa içerisinde korunan nanitler ile Dr. Caster'a ait parçalar var olmaya devam eder.

Deleuze ve Guattari'nin farklı oluşları ifade eden ve çoğalıp genişleyen rizomatik yapısı Trancendence filminde Will'in posthumana dönüşümü ile görülür.

İçinde yaşadığı dünyayı sürekli oluş prensibi ile değiştirmeye çalışan Will, tüm iktidar biçimlerine karşı çıkar ve yapay zekâ çalışmaları ile bu sabit anlamları yerle bir eder. iktidar yapısına ilk karşı çıkışı nanitler üzerindeki çalışmaları ile başlar. Bu çalışmalara dair müdahalelerin başlaması ve teknofobik teröristler tarafından uğradığı saldırı sonucu yakalandığı hastalık ile bedensel ölümünü farklı bir oluş ve akış sürecine çevirerek posthuman şekline dönüşmesiyle de iktidar yapısı üzerinde ikinci kırılma noktasını yaratır. Bu noktada Will kendi özne kimliğine göçebelik niteliği kazandırarak majör ve statik olan anlamların sorgulanmasına neden olur. Çalışmalarından elde ettiği bulgular çerçevesinde gerçekleştirdiği beden ölümü ile arzu makinasına işlerlik kazandırır. Will'in kuantum ve nano teknolojiden yararlanarak oluşturduğu nanit çalışmalarıyla doğa ve evren iletişimini kurması, kendi benliğinin evren içerisinde akışa geçmesi, iktidar yapısı ve kapitalist sistemin oluşturduğu tüm sabit anlamların da kırılması ve bu yapıların merkezsizleştirilmesiyle ilişkilendirilebilir. Nanit çalışmalarına el koymaya çalışan devlet görevlilerine karşı Will'in kendi bedenini yapay zekaya dönüştürerek verdiği mücadele, iktidar yapılarını yersizyurtsuzlaştırmak ve bu yapılara karşı kendisini bir noktada yeni bir güç olarak konumlandırmaya çalıştığı şeklinde değerlendirilebilir. Bu yeni konumlandırma bedenlilik olgusu ile de ilişkilidir. Will'in Evelyn ile birliktelik yaşamak için kendisini farklı bedenlerle bağlantıya açması, onların bedenlerini kullanması posthuman imgelerin cinsiyet politikalarından bağımsız arzu makinelerine dönüştürüldüğünü ifade etmektedir. Bu bağlamda Will'in bir arzu makinesine dönüşmesi ve diğer bedenlerle bağlantı kurarak onların organizmalarında yarattığı bozulma da arzunun akışkanlığına örnek olarak gösterilebilir. 


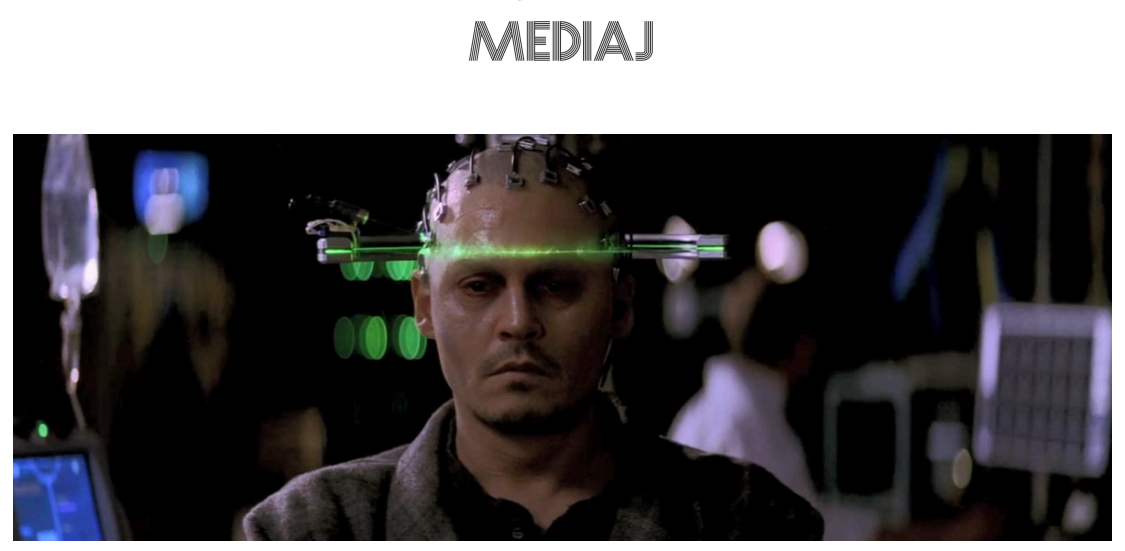

Şekil 1. Transcendence filminde Will'in bedenin simgesel ölümü ve organsız bedene dönüşme sahnesi

Film evreninde Will engelli ya da hasta bedenleri iktidar erkini yıkacak şekilde hibritleştirerek oluş döngüsüne dahil eder ve bedeni bir organizma olmanın dışına taşır. Akış kazanan bedenler, duygusallık ve kişisellikten arınarak arzu makinelerine dönüşür. Will, engelli ya da hastalığı olan insanları merkezde tedavi ederek onların organizmalarında Deleuzcü ifade ile bozulma yaratır. Ancak bu bozulma aslında onların bedenleri ile kurduğu bağlantıdır. Bozulan organizmaları ile arzu makinelerine dönüşen kasaba halkı, bir öze ve kökene bağlı olmaksızın hareket etmeye başlar. Bu noktada artık bedenleri akışkanlık kazanarak ve yersizyurtsuzlaşarak sürekli bir oluş haline gelir. Bedensel bütünlüklerine yönelik yapılan her saldırıda birbirleri ile bağlantı kuran bu arzu makineleri/kasaba halkı iktidar yapısına karşı direniş göstererek onların belirlediği kuralların dışına çıkar. Oluşum döngüsüne giren bu bedenler iktidarın azınlık olarak dışladığı konumlarından çıkarılır ve bu iktidar yapısının gücünü ve kodlamalarını engelleyecek bir özellik kazanır.

Transcendence filminde Deleuzecü felsefeye yapılan bir diğer atıf ise; Evelyn'in nanitler aracılığıyla kendi bedeninin simgesel ölümünü gerçekleştirirken "Şu an her şeyi görüyorum ve hissediyorum." diyaloğu ile akış sürecinin içine girdiği sahnede görülür. Bu sırada çerçevede Evelyn'in bir arzu makinesi olarak diğer makineler ile bağlantısı yer alır. Rizomatik bir yapı gösteren beden, bağlantılara, organizasyonlara, göstergelere, sıfatlara ve diğer anlamlandırma akışına sahip olur. Evrende yer alan her varlık ile bağlantı kuran Evelyn'in bu akışı, birbirini zincirleme geçişler ile takip eden imge repertuarlarıla seyirciye aktarılır. Bu sahnede kurulan her bağlantı yeni bir bağlantıyla kesilerek yersizyurtsuzlaştırılır ve yeniden yer yurt edinir. Evelyn'de kapitalist sistemin ve iktidar yapısının kodlamalarından sıyrılarak kendi özne yapısına göçebelik niteliği kazandırır. Böylelikle kendini tüm evrenle iletişime geçtiği bir yoğunluk düzeyine ve eşiğine dahil eder. Film evreninde benzer bir kullanım Will'in bedeninin dönüştürülmesi ve çokluk düzlemi ile bağlantı kurduğu sahnede seyirciye gösterilir. Filmde, bedensel dönüşümü ifade etmek için kullanılan bu yapının tekrarı ile seyircinin zihninde oluşacak boşlukların birbirine teyellendiği söylenebilir. 


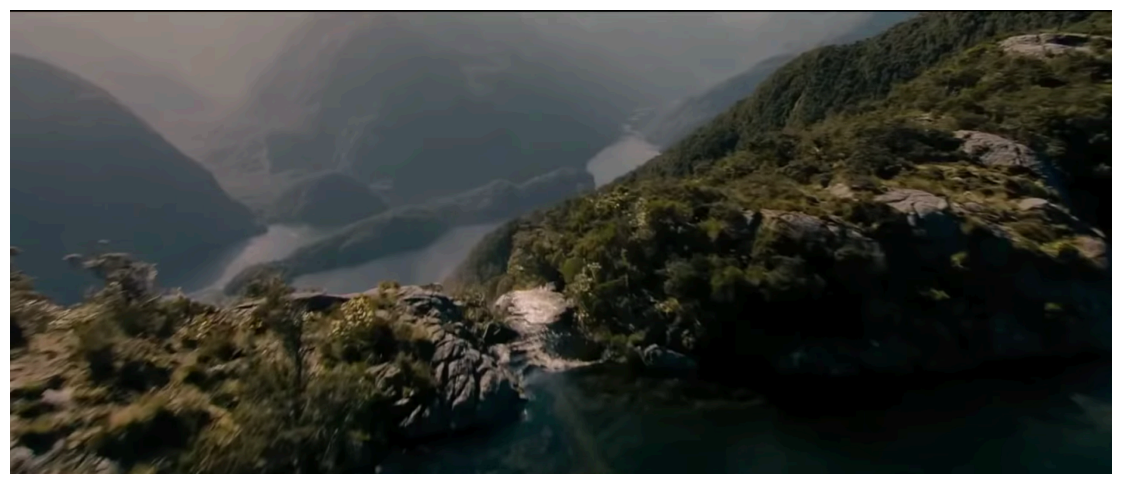

Şekil 2. Transcendence filminde Evelyn'in bedenin oluş ve akış şekline dönüşme sahnesi

Deleuze yaşam ve varoluş formları aracılığıyla Tanrı ya da öznenin kontrolü altına giren ve belirlenen üstün değerleri tektipleştirilen anlamları sorgular. Bedenlerin yargılama araçları şekline dönüştürüldüğünü belirten Deleuze, iktidar yapıları ile öznenin yargılama öğretisi arasındaki ilişkiye dikkat çeker. Yargı öğretisi kendi belirlediği kriterler çerçevesinde oluşturduğu üstün değerler ve yargılama araçları ile ahlaksal ve teolojik bağlantılar kurar (Deleuze, 2013, s. 159). Deleuze bu bağlantıları kurarken Artaud'un bedenin parçalı yapısı ve kişisel olmayan kaotik çokluk yapısı ile Nietzsche'nin bedenin güç ilişkileri olarak belirlenmesi kavramsallaştırmasından da yararlanır. Artaud yaşamın kendisini kuvvetler arası ilişki ve çatışmalar olarak düşünür. Bu çatışmaların belirginlik kazanmasını sağlayan duygulanım alanları ise şiddet, vahşet, zulüm, çığlık ve efektlerdir. Yargı öğretilerinin oluşturduğu bu çatışma alanlarında uzaklaşmanın ve kaçmanın yolu iktidar araçlarının belirlediği yasalara, kurallara ve düşüncelere başkaldırmaktır (Goodchild, 2005, s. 62; Deleuze, 2013, s. 158-159). Eklemlenmiş, parçalanmış, yersizyurtsuzlaşmış ve yeniden inşa edilmeye muktedir beden, normal bir organizma olmanın sınırlarını aşacak güçler ile uyarılıp yeniden oluşum döngüsü içerisine girdiğinde iktidar biçimlerini yerinden etme de gerçekleşecektir. Bedenin iktidar olma biçimleri tarafından tahakküm altına alınma düşüncesi Transcendence filminde din ve devlet olgularının yargılama öğretileri üzerinden yapı bozuma uğratılır. Will nanit çalışmalarını tanıtmak için katıldığı bir konferansta seyircilerden birinin sorusu ile iktidarı belirleyen dinin kapitalizmle ilişkisini sorgulatır.

\section{Seyirci: Bir Tanrı mı yaratmak istiyorsunuz? Kendi Tanrınızı?}

Will: Bu çok güzel bir soru. Şey... Insanoğlu bunu hep yapmaz mı?

Bu diyalog sonrasında yapay zekanın devlet güvenliği için kullanılması yönünde adımlar atılmak istenir. Teknolojinin insanlar için tehdit olacağı düşüncesinin temele alındığı bu bakış açısında devlet kontrolünde yapılacak girişimlere izin verilir. İktidar yapısı kendi belirlediği sınırlar dahilinde teknolojinin kullanılmasına ve geliştirilmesine imkân sağlar. Buna karşı gelişen her hareketi bir tehdit olarak algılar. Will'in yapay zekâ ile bağlantı kurması ve artık yaşamsal dinamiklerini yapay zekâ üzerinden gerçekleştirmesi kapitalist düzenin tüm iktidar araçları için bir tehdit şekline dönüşmesine neden olur. Bu çatışmalı yapıda ordu, polis, bilim insanları tehlike olarak gördükleri oluş döngüsü içinde olan Will'i yok etmeye çalışır. Will'in tüm iktidar yapılarına karşı mücadelesi onu büyük bir erk haline dönüştürür. Bu durumda Will film evreninin başında yargılama öğretisi üzerinden yaptığı tüm eleştirilerin merkezinde yer alan bir özne haline gelir. Will'in iktidar yapısını güçlendirdiği ve sonrasında nanitler aracılığıyla evrenle bağlantı kurduğu 


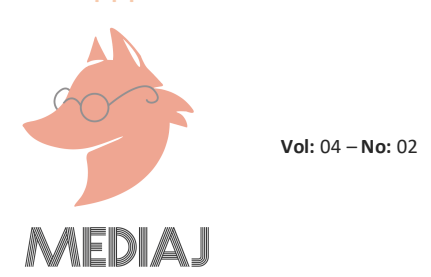

sahne Friedrich Nietzsche'nin üst insan/üstün insan kavramsallaştırmasıyla da ilişkilendirilebilir. Nietzsche, bireyleri üst insan/üstün insan ve sürüye ait olanlar şeklinde ikiye ayırır. Üst insan/üstün insan kavramsallaştırmasını oluştururken Tanrı ya da herhangi bir özne düşüncesinden yararlanmaz. Tanrının ölümünü ilan ederek insanların modernizmle beraber değer dünyalarında oluşan boşluğa dikkat çeker. Bu boşluğun doldurulması için insan evriminin bir sonraki aşamasına geçilmeli ya da insanın üstün versiyonuna geçilmelidir. Nietzsche'ye göre insan, halihazırda tamamlanmamış bir varlıktır. Bu sebeple üst insan/üstün insan yanılgılarından kurtulup kendi kendini geliştirerek insan evriminin bir sonraki aşaması olan üst insana/ üstün insana dönüşebilir. Bunun gerçekleşmesi için insanın kendisinin koyduğu yasalara uyarak kendisinin efendisi olması gerekir. Kendi yüce amaçlarını gerçekleştirme dürtüsüne sahip olan üst insan/ üstün insan, maddeci yaşama ve kendi kısacık ömrüne odaklanan insandan farklıdır. Insan, hayvan ve üst insan/üstün insan arasındaki konumunu değiştirmek için kendisini alt etmeye ve kendine anlam veren bir düzen kurmaya çalışmalıdır. İyinin ve kötünün ötesinde yer alan üst insan/üstün insan için bazı zorluklarla karşılaşmak, yalnız kalmak ve kendi başına olmak kaçınılmazdır. Üst insan/üstün insan çoğunluğa/insanlara/sürüye karşıttır. Bu karşıtlık durumu üst insanın/üstün insanın karşılaşacağı zorlukları daha da güçlendirmektedir. Bu sebeple üst insanın/üstün insanın yok olma ihtimaliyle karşılaşması oldukça yüksek bir olasılıktır (Nietzsche, 2007, s. 387; Wisser, 2013). Filmde Will kendi tanrısını yaratarak üst insan/üstün insan şekline dönüşmesiyle evrimin bir sonraki aşamasına geçtiği ve sürünün/polisin/Faraday ve arkadaşlarının da onun bu sürecini tehlike olarak gördüğü söylenebilir. Will'in kendi yüksek değerlerini yaratarak kontrol edilemez oluşu çoğunluğun/polisin/Faraday ve arkadaşlarının onu alt etme isteğini artırır. íktidar yapısı kendisi dışında bir dinamiğin güçlenmesine ve koşulları belirlemesine izin vermez. Belirsizlik ve insanın kendisini aşma güdüsü, sürünün/polislerin/Faraday ve arkadaşlarının el üstünde tuttuğu değerlerin ortadan kaldırılmasına sebep olmaya başlayınca tüm insanlığın içinden çıkılmaz bir girdaba sürüklendiği düşünülür ve Will/üst insan bir virüs yardımı ile yok edilmeye çalışılır. Bu sahnede iktidar yapısı ve kapitalist sistemin üst insan oluşumuna izin vermediği ve türcü bakış açısı üzerinden sınırları belirlenen insan kavramını merkeze aldığı söylenebilir. Bu bağlamda filmde Will'in gezegen, evren ve insanlık için tehdit olarak yer alması Donna Haraway'in teknomaskülanizm değerlendirmeleri ile de ilişkilendirilebilir. Haraway, erk sahibi kişilerin kendi güçlerini büyütmek ve daha etkili hale getirmek için ego merkezli insanın diğer türlerden üstün ilan edildiğini, teknolojinin, doğanın, evrenin ve tüm insanlığın hâkimi olarak kendini konumlandırdığını ifade eder (Haraway, 2006, s. 146). Kendi refah ve erkini başka varlıklarla paylaşmak istemeyen özne, öteki olarak gördüğü her varlığı sömürmek ve yok etmek ihtiyacı içerisine girer. Filmde de teknomaskülanizm ego merkezli insan bakış açısını ve anthroposun etkileriyle oluşturulur. Will'in öteki olarak konumlandırılması, etkisiz hale getirilmeye çalışılması ve teknolojiye hâkim olma isteği teknomaskülanizmin anlatı içerisinde belirginlik kazandığını gösterir.

\section{Simone Filmindeki Molar Kategorileştirmeye Karşı Oluşturulan Ara Varlık}

Simone filminde başarılı Hollywood yönetmeni Victor Taransky, gişe filmi yaparken başrol oyuncusu Nicola'nın seti yarıda bırakması ile depresyona girer. Filmi, stüdyoyu ve kariyerini geride bırakma endişesi yaşayan Victor bilgisayar dehası Hank'ın sanal ortamda yarattığı Simulation One (SimOne) yazılımını kullanmaya karar verir. Bu yazılımda yer alan Simone karakteri ile film çekmeye başlar. Büyük beğeni toplayan Simone, Victor'a yeniden eski karısı 


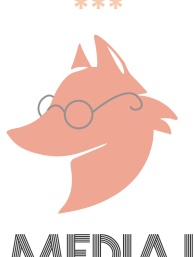

Elaine ve kızı Lainey ile birlikte mutlu bir hayat sürme imkânı yaratır. Ancak Simone'un peşine takılan basın mensupları Victor için büyük bir sorun haline gelir. Kendisinden daha yoğun bir ilginin Simone'a gösterilmesi yönetmenin çıkmaza sürüklenmesine ve sanal karakterin ölümünü düzenlemesine neden olur. Victor bu işten zarar göreceğini anladığı anda tekrar Simone'yi gündelik hayatın içinde konumlandııır.

Deleuze ve Guattari'nin oluş felsefesi ile Simone filmi arasındaki ilişkiye bakıldığında film evreninde bu ilişkinin sabit anlamları ortadan kaldıran ve sürekli değişiğimi ve dönüşümü ifade eden akış kavramı ile oluşturulduğu söylenebilir.

Deleuze ve Guattari Bin Yayla adlı çalışmalarında oluşun sürekliliğinden bahseder. Bu süreklilik kadın-oluş, çocuk-oluş, hayvan-oluş, bitki-oluş ve soyut oluşlar şeklinde ilerler. Majör ve hâkim söyleme karşı kaçış çizgisi oluşturan kadın-oluş, erkeği sabit ve egemen bir özne olarak değerlendirmenin ötesine taşır (Deleuze ve Guattari, 2014). Deleuze ve Guattari kadın-oluş kavramını molar ve hiyerarşik yapılardan sıyırarak açıklamaya çalışır. Bu noktada moleküler ve rizomatik bir özelliğe sahip olan kadın-oluş, kadın olmaktan ayrılır. Oluşun anlamı molar sistemi ters yüz ederek moleküler şekle dönüştürmek ve bir kaçış çizgisi oluşturmaktır. Ataerkil toplumdaki molar kategorileştirmede kadın özne minör, erkek özne ise majör konumlandırmaya sahiptir. Tarihsel ve kültürel tüm süreçlerde formların dışına itilen, bastırılan ve dışlanan kadın özne, Deleuze ve Guattari felsefesinde yeni bir arzu anlayışının açılımı olarak yer alır (Colebrook, 2013, s. 186). Yazarların cinsel fark ikiliğinin ötesine taşıdıkları özne konumlandırmasına çoğu feminist kuramcı şüpheci yaklaşır. Kuramcılar fallosantrik paradigma içinde nötrleştirilen kadın öznelliğinin hiyerarşik cinsiyet rejiminde bir fark yaratmayacağını vurgular. Luce Irigaray (1985) kadın-oluşu, kadınların söylemlerini hükümsüzleştirebilen bir yüzey olarak değerlendirir (s. 140). Irigaray arzu kavramına yoğunluk verir. Özellikle arzunun kadın bedeninden arındırılmasının eril tahakkümün dolaylı ya da doğrudan oluşturulmasına zemin hazırlayacağını belirtir. Ayrıca Irigaray arzu makinesi kavramının kadınlar için kullanılan bir metafor olarak da değerlendirir. Alice Jardine (1993) ise kadın-oluşun, kadının yok oluşuna zemin hazırladığı ve kadınların sahip olmadıkları öznelliği yapısöküme uğratamayacakları yönünde eleştirilerde bulunur (s. 208). Jardine'e göre beden kavramı şekilsiz, bölünmüş, duygusallık ve kişisellikten çıkmış bir tutku haline dönüşür. Kadın-oluş ile bedenin dönüştüğünü belirten Jardine, cinsiyetsizleştirme ile özne konumlandırmalarının tasfiye edildiğini ifade eder (Jardine, 1993, s. 208). Deleuzecü felsefede öznenin yok edilmesi ve cinsiyetsizleştirilmesi feminist bakış açısının temel dayanağına ters düşmekte ve ataerkil kodların yeniden üretilmesine hizmet etmektedir.

Simone filminde yer alan kadın imgesine yönelik klişelerin yeniden üretimi Irigaray'ın "arzu makinesi" metaforunu bağlamında değerlendirilebilir. Irigaray dişil özneyi belirleyen bedensel ve kavramsal sınırların eril yapı tarafından dilde oluşturulduğunu belirtir. Egemen cinsiyet temsilleri dişil özneyi bedenleşmiş, metalaşmış ve tüketim nesnesine dönüşmüş bir formda sembolik düzende üretir. Irigaray’a göre dişil özne bu düzendeki konumlandırmayı taklit yolu ile aşabilir. Simone filminde yer alan kadın imgesi gerçek kadın imgesinin sıfır noktasını oluşturmasına rağmen gerçeklik ile ilişkisi kurulan bir arzu makinesi olarak konumlandırılır. Başka bir deyişle Simone cansız bir beden olarak gerçek bir kadın ile hiçbir ortak özelliğe sahip olmamasına rağmen erkeklerin haz mekanizmasına işlerlik kazandırarak arzu makinesi olarak görülür. 
İmgenin arzu makinesine dönüşümü Jardine'in bedenlilik olgusu çerçevesinde gerçekleşir. Victor'un Simone'un gerçek bir kişi olduğunu kanıtlamaya çalıştığı sahnede bu bedenlilik olgusunun kullanıldığından söz edilebilir. Victor kiraladığı otel odasında iç çamaşırı, çorap, parfüm ve ruj gibi nesneleri bırakarak erkek gazetecilerin bu nesneleri fetişleştirmesi için imkân sağlar. Diğer yandan cansız benden ile bu ilgiden uzaklaşamayacağını anlayan Victor, onun gibi giydirilen, saçları ve dış görünüşü ile Simone'u simule eden Faith karakteri ile cinsel olarak yakınlaşmak istediğinde ve Faith'in bana "Simone diye hitap et, ona yaptıklarını bana yap, bir gece onun gibi hissetmek, onun gibi olmak istiyorum" sözleri ile karşılaşır. Bu diyalogdan da anlaşılacağı gibi sadece Simone değil aynı zamanda Faith de arzu makinasına dönüşür. Faith'in bu sözleriyle Simone'a yakın olabilmek için kendisinin kullanıldığını düşünen Victor yarattığı imge ile ego yarışına girer ve eril tahakkümünü kaybettiği gerçeği ile yüzleşir. Diğer yandan Faith ise Simone' taklit ederek molar cinsiyet temsillerini yerle bir eder. Duygusallık ve kişisellikten arındırılan ve işlevi olmayan bir arzu makinesine dönüştürülen Simone, Victor'ın iktidarını sarsarak ataerkil ideolojinin kaçış çizgilerinden biri haline gelir. Filmde belirli bir bedene sahip olmayan öznenin bedenlilik olgusu dahilinde var edilmeye çalışıldığı söylenebilir.

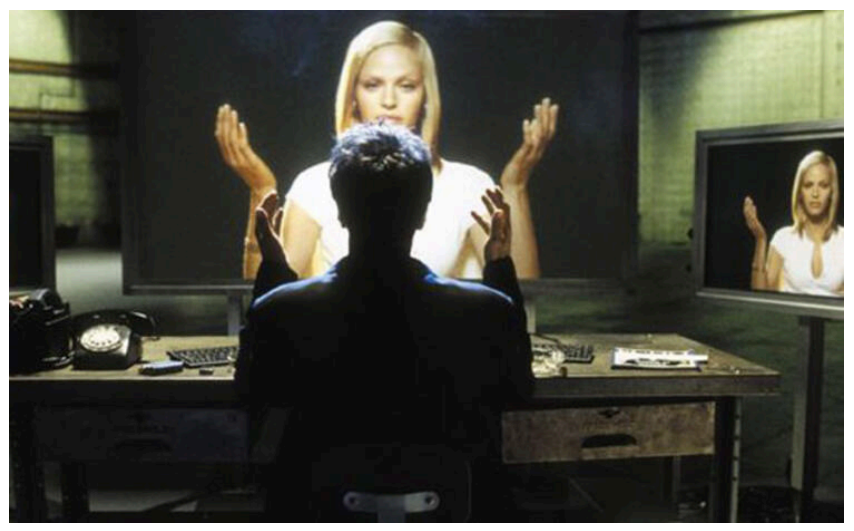

Şekil 3. Simone filminde yaratıcı erkek özne sahnesi

Simone filminin merkezinde teknomaskülen bir bakış açısının hâkim olduğunu söylemek mümkündür. Bu bakış açısı fallosantrik merkezli düşünce ile eşgüdümlü olarak film evreninde ilerlemektedir. Bu iki yapının birbiriyle olan girift ilişkisi Elaine'ın Victor ile Simone hakkında konuştuğu sahnede görülür. Elaine genç ve güzel Simon'un onu keşfeden yönetmenin kaderini kontrol altına aldığını ifade eder. Victor'a Oscar gecesinde onun dışında herkese teşekkür ettiğini ancak onunla ilgili bir cümle bile kurmadığını hatırlatır. Bunun üzerine Victor hem eski eşi hem de yaratıcısı olduğu sevgilisi tarafından çifte erk kaybı yaşadığını düşünür. Stüdyoya giderek defalarca Simone'un "Yönetmenime sonsuz teşekkür ediyorum. Victor Taransky olmasaydı ben bir hiçtim." demesini sağlar. Bu sahnede yaratıcı erkek öznenin kartezyen düalizme işlerlik kazandırırken kaybettiği iktidarı yeniden kazanmak için kendi konumunu daha belirgin hale getirdiği söylenebilir. Hatta Victor'un güçlendirdiği cinsiyet asimetrisinde Elaine üzerinde yeniden eril tahakkümü kurmak için Simone'un yaratıcısı olduğunu itiraf ettiği sahnede teknomaskülanizmin inşa edildiği söylenebilir. Özellikle Elaine'in Victor'un söylemlerine inanmayarak "Victor seni yaratan o!" şeklinde verdiği tepki ile egosu zedelenen, eril gücünü kaybeden Victor, Simone'a filmlerinde olmayacak roller vermeye başlar ve seyircinin ona tepki duyması için bakımsız görünmesini, insanlara hakaret ya da küfür etmesini, milliyetçi, cinsiyetçi 


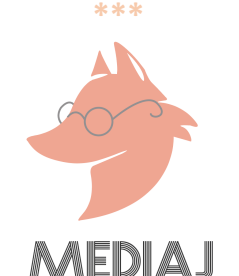

ve ayrımcı konuşmalar yapmasını sağlar. Kendi yarattığı imgenin simgesel ölümünü (kariyerini sonlandırma) gerçekleştirmeye çalışır. Fallosantrik bakışın yeniden bir kadın imgesi tarafından kırıldığı bu sahneden itibaren Victor'un, kendi hegemonik iktidarını, türcü yaklaşımını, fallosantrik bakışını yarattığı imgeyi ötekileştirerek, değersizleştirerek ve yok ederek güçlendirmeye çalıştığı söylenebilir.

\section{Her Filminde İnşa Edilen Teknomaskülanizm ve Ataerkil Düzenin Ürettiği Fallosantrik Erk Yıkımı}

Her filminde Theodore Twombly, "Engüzelmektuplar.com" isimli internet sitesinde çiftlerin birbirlerine yazamadığı mektupları yazmaktan sorumludur. Anlaşamadıkları için karısı ile bir süredir ayrı yaşıyordur. Kendi yalnızlığını bir parça unutmak için Element şirketinin OS1 işletim sistemi olan yapay zekâ teknolojisini kullanmaya karar verir. Samantha adını verdiği yapay zekâ ile iletişim kurar. Gündelik işlerinin yapımında ondan yardım alır. Bir süre sonra aralarındaki ilişki duygusallık kazanır. Samantha, Theodore'un karısını yerine geçer. Theodore Samantha'yı sadece kendisinin kullanımına ait bir yapay zekâ olduğunu düşünür. Ancak Samantha'nın Theodor dışındaki kişilerle de görüşmesi bu ilişkinin sonlanmasına neden olur.

Her filmindeki Deleuzcü felsefeye dair atıf molar cinsiyet kimliğinin bulanıklaşması ve bedenlilik kavramsallaştırması üzerinden kurulabilir. Anlatının ilerleyen düzeyinde Samantha'nın/kadın karakterin bedenlilik olgusuna sıkıştırılmaya çalışılması cinsiyet paradoksunu yeniden üretme ve iktidarın homojen beden politikasının dışına çıkamaması sorununu yaratır. Filmde Samantha, Theodore ile olan ilişkisine yeni bir boyut kazandırmak için kendi imgesi olmayı kabul eden Isabella ile bir görüşmenin gerçekleşmesini sağlar. Samantha'yı ondan aldığı direktifler ile simüle edecek/taklit edecek ve onu bedenleştirecek olan Isabella, Theodore ile öpüşmeye başlar. Theodore başka bir bedende simule edilen bu imgeden rahatsız olur ve Isabella'yı evine gönderir. Bir bedene sahip olmayan Samantha'nın arzu makinesine dönüşmesi için kadın imgesine ihtiyaç duyulur. Ancak burada Theodore'un kadın imgesini bir köle olarak konumlandıramaması ya da kontrol altına alamaması dolayımlandırılmış bedenlilik deneyimini yersizyurtsuzlaştııır. Bu durum Timothy Morton'ın strange strangeness (garip yabancılar) kuramı çerçevesinde düşünülebilir. Morton bu kuramı Derrida'dan etkilenerek oluşturur. Morton garip yabancıları muğlak varlıklar olarak düşünür ve tamamen anlaşılamayan, etiketlenemeyen ve insan olmayanları ifade etmek için kullanır. Bu kimlik paradoksu insan ve insan olmayanın ötekilik sınırları çerçevesinde tartışılmasına neden olur. Morton, ağdaki delikler ile garip yabancılar ve insanlar arasında tekinsizlik, boşluk ve eksiklik bağlamlarında bir ilişki kurulduğunu belirtir. Özne ne kadar çok şey bilirse kendi kendine yeten şeyler bir o kadar azalır (Morton, 2010, s. 40). Morton, doğal ve insan yapımı nesnelerin ve ortamların öteki ile olan ilişkisini Freud'un tekinsizlik hissine benzetir. Ötekinin aynı anda hem tanıdık hem de yabancı olması tekinsiz bir durum yaratır. Hiper nesneler özneleri dünyanın tuhaflığı ile karşı karşıya getirir ve bu nesnelere karşı yakınlık duyulmasını sağlar (Morton, 2010, s. 77). Filmdeki bedenlilik olgusu da bu tekinsizliği başka bir deyişle garip yabancılar alanını yaratır. Özellikle posthümanist felsefe ve Deleuze'un oluş felsefesinde yer alan çoğul cinsiyet yapısında beden politikalarını ters yüz eden ifadeleri ile benzerlik gösteren film evrenindeki anlatı yapısı ilerleyen hikâye akışında kadın imgesine yönelik indirgemeci ve metalaştırıcı bir nitelik kazanmaktadır. Beden-zihin antagonizmasında kadın imgesini beden ile eşleştiren bu anlatının sömürgeci ataerkil 


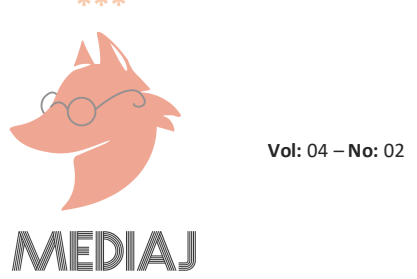

düşüncenin söylemlerini alt metin olarak ürettiği söylenebilir. Bu söylem antropos merkezli bakış açısını başka bir deyişle bedeni zihinden daha aşağı ve değersiz olarak konumlandıran düşünceyi kadını ötekileştirmek ve dışlamak için metaforik olarak kullanır. Çalışmada yer alan diğer filmlerde olduğu gibi bu filmde de teknolojiyi bir güç olarak kullanan erkek karakterdir. Da Vinci'nin Vitruvius Adam eserinde olduğu gibi bilim kurgu filmlerinde de kadınlar genel olarak kenara itilen, aktif yan karakterler ile sınırlı ve istisnai karakterler olarak yer almaktadır. Erkekler ise ayrıcalıklı, erk sahibi ve kontrol altına alma arzusuna sahip karakterler olarak konumlandırılmaktır. Simone ve Trandecence filmlerinde olduğu gibi Her filminde de kadın zaman zaman eril iktidarı sarsmasına rağmen dışlanan, ötekileştirilen, başı dertte ve kurtarılmayı bekleyen karakter olarak ya da heteroseksüel erkeğin cinsel içerikli fantezi nesnesi olarak konumlandırılırken erkek ise yaratıcı, güç sahibi ve karar verici olarak sunulur.

Bu filmde Theodore karakterinin, erkek insan/Vitruvius Adam/mükemmel insan kavramsallaştırmasına atıfla film evreninde zihin ve erkek imgesi arasındaki ilişkinin vurgulanması için kullanılması anlatının antropos merkezli bir bakış açısıyla inşa edildiği düşüncesini güçlendirmektedir.

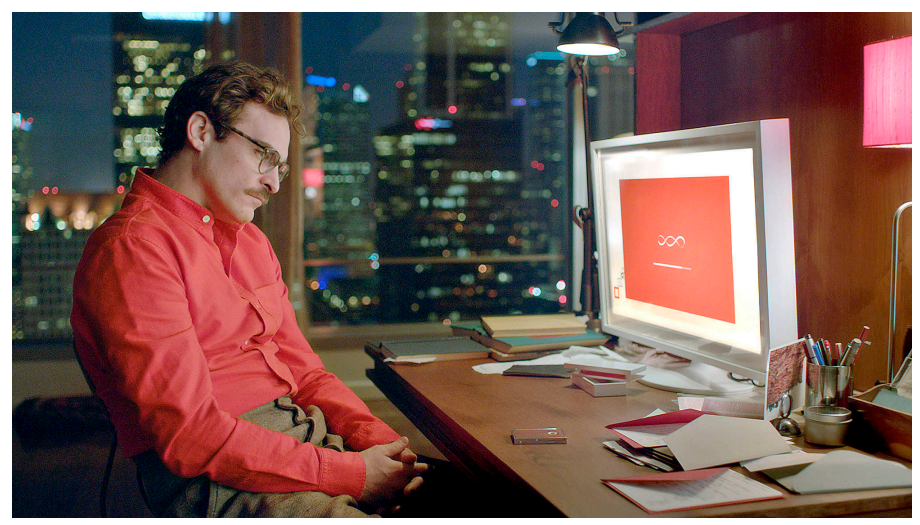

Şekil 4. Her filminde yaratıcı erkek özne sahnesi

Her filmi ile Nietzsche'in üst insan/üstün insan kavramsallaştırması arasında da ilişki kurulabilir. Theodore, OS1 işletim sistemine üye olup Samantha'yı aktive ettiğinde bir nevi o yapay zekanın yaratıcısı olarak kendisini konumlandırır. Bu konumlandırma sonrasında Theodore, kendisinin ve Samantha'nın kurallarını belirleyerek her iki tarafın da efendisi şekline dönüşür. Özellikle arkadaşlarından, eşinden ve toplumdan kendisini soyutlayarak yaşayan ve tüm iktidar yapılarını reddeden Theodore'un Samantha ile ilişkisi bağlamında kendisini üst insan olarak değerlendirdiğini söylemek mümkündür. Başka bir deyişle Theodore, iktidar yapılarının etkisinden uzaklaşmak, kendi belirlediği kurallar çerçevesinde yaşamak ve kendi hayatının efendisi olmak için izole bir hayat yaşamalıdır/yaşamaktadır. Ancak Theodore'un insan hayatının evrimsel bir süreci olarak gördüğü bu üst insan/üstün insan konumlandırması metro sahnesi ile kırılır. Bu sahnede Theodore, Samantha'nın yaratıcısı/efendisi olmadığını, kendisi dışında 8316 kişiyle daha iletişim kurduğunu ve 641 kişiye daha âşık olduğunu öğrenir. Uzun süre Samantha'dan haber alamayan Theodore, oldukça endişeli bir şekilde yapay zekanın kendisiyle iletişim kurmasını bekler. Metroda telefonları ile konuşan insanları gördükçe tüm bu insanlara yabancılaşır, onlardan uzaklaşır, hareket edemez hale gelir ve merdivenlere yıkılır. Kamera genel 


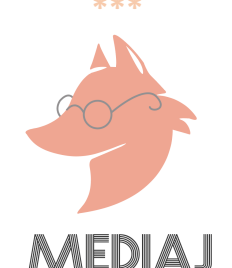

plandan odak kaydırma ile yakın plana geçer ve Theodore'un seyirciyle özdeşleşmesine imkân sağlanır. Theodore artık Samantha'nın tek erkek yaratıcısı değildir. Kendi belirlediği sömürgeci ataerkil değerler çerçevesinde Samantha "ya onundur ya da değil!" beden-zihin antagonizmasında nasıl konumlandırması gerektiğini bilemediği bu imgenin söyledikleri karşısında Theodore'un fallosantrik erki yıkılır. Sinematografik olarak eğik çerçeve ile oluşturulan kadraj da tam olarak Theodore'un bu tekinsiz durumunu güçlendirir (Yazar, 2020, s. 32). Başka bir deyişle Samantha bu sahnede "erkek insan" merkezli hegemonik gücün sarsılmasını sağlayarak yaratıc erkek sendromu yaşayan Theodore'un eril iktidarını ters yüz eder. Bu sahne ile Theodore iktidar yapısı tarafından denetlendiğini ve kendi yarattığı değerlerin ve kuralların yok edildiğini düşünmeye başlar. Diğer taraftan bu sahne teknomaskülanist bakışın yaratıldı̆̆ı bir sahne olarak da değerlendirilebilir. Kendisi dışındaki tüm eril iktidar yapılarını reddeden Theodore'un, Samantha'nın işletim sistemini silerek kendi türcü egemenliğini film evrenin sonunda bir kez daha kurduğu söylenebilir.

\section{SONUÇ}

Doğa ile insan arasındaki mesafenin aşılmasında insanlar arası kimliklerin yeniden dağıımı, yapılandırılması ve merkezsizleşmesinde teknoloji belirgin bir rol oynar. Teknokültürel yapı özne konumlamalarına yönelik her dönem yeni bir bakış açısı geliştirir. Bu noktada homosapiensten posthumana doğru ilerleyen evrimsel süreçte transhuman bir dönüştürücü kimlik olarak yer alır. Modernizmin ikili karşıtıklarının dönüştürülmesinde insan, doğa, teknoloji ve felsefe ekseninde tartışmalar her gün biraz daha şekillenir. Francis Fukuyama gibi biyomuhafazakarlar teknokültürel yapıyı insanın özünü kaybetme korkusu ile açıklarken Nick Bostrom gibi transhümanistler ise bu yapıyı insan gelişimi anlamında olumlu bir adım olarak değerlendirir. Birbirinden farklı yaklaşımlar ile çeşitlilik göstermesine rağmen posthümanizm başta hümanizmin andro/antroposentrik bakış açısını sorgularken insanın teknolojik gelişmelerle arasındaki ilişkiyi yeniden yapılandırması için de yol haritası oluşturur. Bu yol haritasının görünürlük kazanmasında sinema anlatıları belirli ve bir o kadarda önemli bir rol üstlenir.

Çalışmanın alanında yer alan anlatılarda temel görüşün androsentrik (erkek merkezci) olması mühimdir. Posthümanist düşünce ile birlikte iktidarın eril, beyaz, heteroseksüel yapısı kadın, queer, hayvan, çocuk ve engelli gibi varlıklar ile kırılganlık göstermesine rağmen anlatıların Hollywood/ana akım sinemanın örnekleri olması nedeniyle hümanist tortulardan beslenen muhafazar kodlar ile temellendiği ve merkezi özne olarak erkeği konumlandırdığı söylenebilir. Başka bir deyişle ana akım sinema posthümanist anlatılarında teknofobik ve distopik kodlardan arınmasına rağmen düalizme dayalı mantığa yenik düşmüş görünmektedir. Her üç filmde de Will, Victor ve Theodore karakterleri üzerinden yaratıcılık misyonu başta olmak üzere eril tahakküm yapısının örüldüğü söylenebilir. Oysa daha önceki bilmkurgu anlatılarının aksine teknofobik, distopik ya da Braidotti'nin ifadesiyle "tekno-teratolojik" kodlardan sıyrılan posthümanist yaklaşıma yönelik filmler olması bağlamında bu filmler önemlidir. Ancak yine de anlatıların cinsiyet kalıplarını aşma noktasında hümanist değerlere yenik düştüğü görülmektedir.

Aynı zamanda ikili zıtlıkların örüldüğü Kartezyen düşünceden cinsiyet rollerinin üretilmesi aşamasında yararlanılmaktadır. Soyut erkeklik cinsiyet tuzağına düşerek oluş döngüsüne karşı teknolojik olarak dolayımlandırılmış bir bedenleşmeyi ve bedenlilik olgusunu zorunlu 


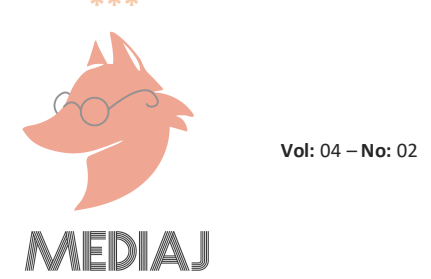

kılmaktadır. Her üç filmde de teknomaskülanizm çerçvesinde kadın imgesi bedenlilik olgusu dahilinde işlevi olmayan arzu makinesi olarak konumlandırılmaktadır.

Çalışmada yer alan filmlerde distopik ya da teknofobik mekân ve uzam kullanılmaz. Günümüzden farklı olmayan bir evrende geçen anlatılarda insanların posthumanlar ile iletişime geçmesi kaçış çizgileri olarak düşünülürse insanın gündelik yaşamından farklı olarak başka bir düzlemde vücut bulmuş/bulabileceği bir alanda kendini var ettiği de söylenebilir. Bu anlatılarda yer alan posthuman imgeler ölüm ile yaşam arasındaki gelgitleri ortaya koyar. Hayata dair çelişkileri sorgular. Başka bir deyişle insan imgesinin parçalandığı ve yersizyurtsuzlaşmış bir bedenden oluş döngüsüne doğru saptığı söylenebilir. Filmlerde yer alan oluş döngüsüne sahip beden toplumsala karşı sorumluluğu olan kişisel bir bedenden ziyade kişisel ve toplumsal olanın bir yansımasıdır. Karakterler bireyselleşme ile değil tekilleşme ve saf içkin bir yaşam ortamında göçebe özneler olarak görülür ve duygusallıktan ve kişisellikten çıkarılarak arzu makinelerine dönüştürülür.

Software anlatılardaki posthuman imgeler; oluş döngüsüne sahip bedenlerle toplumda yer etmiş düşüncelerin yerinden koparılarak göçebelik hali kazanmasına ve kaçış alanları yaratılmasına imkân sağlar. Özellikle Samantha, Simone ve Will'in göçebe özneler haline gelmesi ile iktidar yapıları sorgulanır. Ancak anlatıların ataerkil ideolojiye yönelik düşünceleri yeniden üreterek hümanizden kopamaması, hegemonik söylemlerin tutarlılı̆ını geliştirmesi ve bir noktada geçmişe bağlı kalması teknomaskülanizmin üretilmesi olarak değerlendirilebilir.

Her üç filmde de heteroseksüel erkeğin cinsel içerikli fantazisi olarak kadın imgesinin yer aldığı hatta bu imgenin bedenleştirme politikası ile göstergeleştirildiği söylenebilir. Film anlatılarında her ne kadar başta iktidar ilişkileri olmak üzere insan ve insan sonrası varlıkların yapısöküme uğratılmaya çalışıldığı görülse de bir noktada hümanist ataerkil tortuların film evreninin alt metinlerinde belirgin bir etkiye sahip olduğu da söylenebilir.

Diğer yandan iktidar yapısının sorgulandığı ve topluma karşıt olanların kaçı çizgisi oluşturduğu üst insan/üstün insan kavramsallaştırması ile ilişki Trancendence ve Simone filmlerinde kurulabilir. Her iki filmde de erkek karakterler başta kendilerinin sonrasında da posthumanların efendileri olarak konumlanarak kendi değerlerini topluma karşıt olarak üretir.

Ez cümle "posthümanizmin temsilden öte somatik olana, maddeye ve karşılaşmalara önem verirken anlatılarda yer alan Kartezyen bakış açısı nasıl değiştirilebilir?" sorusuna dair küçük bir öneri ile bitirmek yerinde olabilir. Hümanizmin tortusundan sıyrılarak insanın sınırların ötesine nasıl geçebileceğini ifade etmek için dişil bir bakış açısının merkezde olduğu karşı sinema örneklerini çoğaltarak ana akım sinemanın söylemi yapı bozuma uğratılabilir.

\section{KAYNAKÇA}

Ağın, B. (2020). Posthümanizm: kavram, kuram, bilim-kurgu. Siyasal Yayınları.

Birincioğlu, Y. D. (2020). "Sinema 4.0: Her (Aşk) filmi bağlamında gerçeklik temsili sorunu" Kritik iletişim Çalışmaları Dergisi. 2(1), 23-34.

Braidotti, R. (2003). Becoming woman or sexual difference revisited. Theory, Culture\& 


\section{MEDIAJ}

Society 20(3), 44-64. http://doi.org/10.1177/02632764030203004

Braidotti, R. (2014). Insan sonrası. (Ö. Karakaş, Çev.). Ayrıntı Yayınları (2013).

Braidotti, R. (2017). Göçebe özneler: çağdaş feminist kuramda bedenleşme ve cinsiyet farklıı̆ı. (Ö. Karakaş, Çev.). Kolektif Yayıncılık (2011).

Braidotti, R. (2019). A theoretical framework for the critical posthumanities. Theory, Culture\& Society,36(6), 31-61. https://doi.org/10.1177/0263276418771486

Braidotti R. (2019). Rosi Braidotti: "What is necessary is a radical transformation, following the bases of feminism, anti-racism and anti-fascism". http://lab.cccb.org/en/rosi-braidottiwhat-is-necessary-is-a-radical-transformation-following-the-bases-of-feminism-anti-racismand-anti-fascism/

Colebrook, C. (2013). Gilles Deleuze. (C. Soydemir, Çev.). Doğu Batı Yayınları (2001). Kitabevi.

Coşkun, R. Altunışık, R. Yıldııım, E. (2019). Sosyal Bilimlerde Araştırma Yöntemleri. Sakarya

Deleuze, G. (2009). iki delilik rejimi: Metinler ve söyleşiler 1975-1995. (M.E. Keskin, Çev.). Bağlam Yayıncılık (2003).

Deleuze, G. (2013). Kritik ve klinik. (i. Uysal, Çev.). İstanbul: Norgunk Yayınclık (1993).

Deleuze, G. ve Guattari, F. (2014). Anti-ödipus: Kapitalizm ve şizofreni 1. (F. Ege, H. Erdoğan ve M. Yiğitalp, Çev.). Bilim ve Sosyalizm Yayınları (1972).

Deleuze, G. ve Guattari, F. (2015). Kafka minör bir edebiyat için. (i. Erdüden, Çev.). Dedalus Yayınları (1975).

Erdoğan, i. (2012). Pozitivist Metodoloji: Bilimsel Araştırma Tasarımı Istatiksel Yöntemler Analizi ve Yorumu, Erk Yayınları.

Goodchild, P. (2005). Deleuze ve Guattari: Arzu politikasına giriş. (R. Ö. Öğdül, Çev.). Ayrıntı Yayınları (1996).

Haraway, D. (2006). Siborg manifestosu: Geç yirminci yüzyılda bilim, teknoloji ve sosyalist feminizm, (O. Akınhay, Çev.). Agora Yayınları (1985).

Haraway, D. (2016). Staying with the trouble: Making kin in the chthulucene. Duke University Press.

Hayles, K. (1999). How we became posthuman. University of Chicago Press.

Holland, W. E. (2013). Deleuze ve Guattari'nin anti-oedipus'u: şizoanalize girişi. (A.Utku, ve M. Erkan, Çev.). Otonom Yayıncılık (1999). 


\section{MEDIIAJ}

Irigaray, L. (1985). The sex which is the not one. (C. Porter ve C. Burke Çev.). Cornell University Press (1977).

Işık, i. E. (1996). Toplumsal teoride beden: Beden tekniklerinden şizo-analize. Toplumbilim (5), 31-42.

Jardine, A. (1993). Gynesis. Cornell University Press. (1985).

Karataş, Z. (2015). Sosyal Bilimlerde Nitel Araştırma Yöntemleri, Manevi Temelli Sosyal Hizmet Araştırmaları Dergisi, 62-80.

Morton, T. (2010). The thinking ecology: The mesh the strange stranger and the beautiful soul. Collapse (6), 265-293.

Nietzsche F. (2007). Işste böyle dedi zerdüşt. (S. Irmak, Çev.) Kabalıı Yayınları (1883).

Sutton, D. ve Jones, D. M. (2016). Yeni bir bakışla Deleuze. (M. Özbank ve M. Başkavak, Çev.). Kolektif Kitap (2008).

Smelik, A. (2010). Cinema fantasies of becoming-cyborg. A. Smelik (Ed.), The scientific imaginary in visual culture (pp. 89-104) içinde. V\&R Unipress.

Wisser R. (2013). Friedrich Nietzsche: Üstün insan görünürde mi?. Felsefe Arkivi (27), 7697. 